\title{
The research of the probabilistic characteristics of exhaust emissions from vehicle engines
}

\begin{abstract}
The influence of the probability density of the average speed on the probability density of the specific road exhaust emissions has been analyzed in the paper. The characteristics of the exhaust emissions from internal combustion engines warmed up to normal operating temperature have been examined. The research has been carried out for characteristics of the exhaust emissions from internal combustion engines of passenger vehicles. The research has been carried out for two kinds of functions in the form courses of average speed: of constant and normal distribution. The Monte Carlo Method has been used in the research. The probability density of the specific road exhaust emissions has been estimated. The zero-dimensional characteristics: the median, the kurtosis and the skewness coefficient, have been examined. A significant regularity of the displacement of the probability density towards smaller values in relation to the average speed probability density has been ascertained.
\end{abstract}

Keywords: exhaust emissions, probability density, Monte Carlo Method

\section{Badania charakterystyk probabilistycznych emisji zanieczyszczeń z silników samochodowych}

\begin{abstract}
W artykule przeanalizowano wpływ gęstości prawdopodobieństwa prędkości średniej samochodu na gęstość prawdopodobieństwa emisji drogowych zanieczyszczeń. Rozpatrywano charakterystyki emisji zanieczyszczeń z silników nagrzanych do temperatury normalnej eksploatacji. Badania przeprowadzono dla charakterystyk emisji zanieczyszczeń z silników spalinowych samochodów osobowych. Wykonano je dla dwóch rodzajów wymuszeń w postaci procesów prędkości średniej samochodu o rozkładach: statym i normalnym, stosując metodę Monte Carlo. Wyznaczono gęstości prawdopodobieństwa emisji drogowej zanieczyszczeń. Badano również charakterystyki punktowe rozpatrywanych zbiorów: medianę, kurtozę $i$ wspótczynnik skośności. Stwierdzono wyraźna regularność przesuwania się gęstości prawdopodobieństwa emisji drogowej zanieczyszczeń w stronę mniejszych wartości w stosunku do gęstości prawdopodobieństwa prędkości średniej.
\end{abstract}

Słowa kluczowe: emisja zanieczyszczeń, gęstość prawdopodobieństwa, metoda Monte Carlo

\section{Introduction}

There is mathematical operator dependence between the exhaust emissions from combustion engines under dynamic conditions and the engine states [3-5]. The engine operating states can be described with their thermal states and the intensity of their operation characterized by the engine speed and loads - most frequently torque $[3,4]$. In the tractive operating conditions the basic process determining the ecological properties of combustion engines in terms of the exhaust emissions is the vehicle speed [3, 4]. Hence, the exhaust emissions from vehicles under dynamic conditions are characteristic of each course of vehicle speed and each course of speed can be treated in comparable vehicle operating conditions as a realization of the stochastic process [3, 11].

Because of the needs of evaluation of the exhaust emissions it is advised to correlate these emissions with the point characteristics (zero-dimensional) of the stochastic processes of the vehicle speeds. We know from experience that there is a high efficiency of usage of the characteristics of dependence of the exhaust emissions on the average vehicle speed $[1,3,4,6]$. Such characteristics are usually determined on the chassis dynamometer where driving tests are performed of different courses of speed, simulating real driving conditions of vehicles. Besides typical driving tests used in the homologation procedures such as $[1,4]$ : European UDC

\section{Wprowadzenie}

Emisja zanieczyszczeń z silników spalinowych w warunkach dynamicznych jest zależna od stanów pracy silnika w sposób operatorowy [3 - 5]. Stany pracy silnika mogą być opisane stanem cieplnym silnika oraz intensywnością pracy, którą charakteryzuje prędkość obrotowa i obciążenie - najczęściej moment obrotowy [3,4]. W warunkach użytkowania trakcyjnego podstawowym procesem determinującym właściwości ekologiczne silników samochodowych ze względu na emisję zanieczyszczeń jest prędkość pojazdu [3, 4]. W związku z tym emisja zanieczyszczeń z silników samochodowych w warunkach dynamicznych jest znamienna dla każdego konkretnego przebiegu prędkości pojazdu, a każdy przebieg prędkości może być traktowany w porównywalnych warunkach użytkowania samochodu jako realizacja procesu stochastycznego $[3,11]$.

Ze względu na potrzeby szacowania emisji zanieczyszczeń jest celowe uzależnienie tych emisji od charakterystyk punktowych (zerowymiarowych) procesów stochastycznych prędkości pojazdu. $Z$ doświadczenia jest wiadome, że duża jest skuteczność posługiwania się charakterystykami zależności emisji drogowej zanieczyszczeń od prędkości średniej samochodu $[1,3,4,6]$. Charakterystyki takie są wyznaczane zazwyczaj na hamowni podwoziowej, na której są wykonywane testy jezdne o różnych przebiegach 
(Urban Driving Cycle) and EUDC (Extra Urban Driving Cycle), American FTP 75 (Federal Transient Procedure) and HWFET (Highway Fuel Economy Test), or the Japanese test Japan 10-15 Mode Cycle also special tests are applied. These are for example the stop-and-go tests used in the exhaust emission models developed at INFRAS AG. The tests simulate very high traffic congestion where the average speed is lower than $6 \mathrm{~km} / \mathrm{h}$ and the Autobahn test for the simulation of vehicle traffic on expressways.

Another zero-dimensional characteristic used in the exhaust emission tests is the average value of the absolute value of the product of the vehicle acceleration and speed $[1,3,4,6]$. For the modeling of the vehicle exhaust emission level the engineers frequently use the dependence of the road emissions or emission intensity on two quantities that characterize the course of the vehicle speed: average value of the speed and the average value of the absolute product of acceleration and speed $[1,3,4]$.

In this paper the exhaust emission characteristics in the form of the relation between the emission and the average vehicle speed has been discussed. The tests are performed for the joint category of passenger vehicles, comprising gasoline and diesel engine vehicles of different capacities and different environmental standards $[1,2,4,6,9]$. The structure of the vehicles in terms of their number and intensity of operation (mileage) was assumed on the level from 2009 in Poland. To this end the models of structure were used (developed for The Western Europe - the German model) [1] as well as the model of 'automotive industry lag' in Poland developed by the author $[2,3]$. For the investigations the case of engines warmed up to the regular operating temperature were applied.

\section{The investigations of the probabilistic processes of exhaust emissions from vehicle engines for different average vehicle speeds}

Figures $1-4$ present the characteristics of the exhaust emissions as the dependence of the road emissions from the engines of passenger vehicles on the average speeds. The emissions that are under analysis are carbon monoxide $\mathrm{CO}$, hydrocarbons $\mathrm{HC}$, nitric oxides $\mathrm{NO}_{\mathrm{x}}$ and particulate matter $\mathrm{PM}$. These characteristics were determined with the use of the databases contained in INFRAS AG [9].

The simulation research on the exhaust emissions was performed with he use of the Monte Carlo method $[6,10]$. The average value was assumed as the point characteristic of the course of the speed. In the research the average value is treated as an incidental value that characterizes the stochastic process, hence the research on the exhaust emissions is carried out for the stochastic processes of different characteristics and different average value in particular. In this paper the author discusses two courses of average speeds of vehicles of distributions: constant (even) and normal. The discrete value of the courses of average vehicle speed were determined for each course in 15000 points with the use of the generator of pseudo random numbers - a part of the Statistica software. prędkości, symulujące rzeczywiste warunki ruchu pojazdów. Oprócz typowych testów jezdnych, wykorzystywanych w procedurach homologacyjnych, takich jak [1, 4]: europejskie UDC (Urban Driving Cycle) i EUDC (Extra Urban Driving Cycle), amerykańskie FTP 75 (Federal Transient Procedure) i HWFET (Highway Fuel Economy Test), czy japoński Japan 10-15 Mode Cycle, stosuje się również testy specjalne. Są nimi przykładowo w modelu emisji zanieczyszczeń, opracowanym w INFRAS AG: Stop and Go - test symulujący warunki o znacznym utrudnieniu ruchu pojazdów (kongestia) o prędkości średniej mniejszej niż $6 \mathrm{~km} / \mathrm{h}$ oraz test Autobahn do symulacji ruchu samochodów na autostradach i trasach szybkiego ruchu.

Inną charakterystyką zerowymiarową stosowaną w badaniach emisji zanieczyszczeń jest wartość średnia wartości bezwzględnej iloczynu przyspieszenia i prędkości pojazdu $[1,3,4,6]$. Często wykorzystuje się do modelowania emisji zanieczyszczeń z pojazdów zależność emisji drogowej lub natężenia emisji zanieczyszczeń od dwóch wielkości, charakteryzujących proces prędkości jazdy samochodów: wartości średniej prędkości oraz wartości średniej wartości bezwzględnej iloczynu przyspieszenia i prędkości pojazdu $[1,3,4]$.

W niniejszym artykule rozpatruje się charakterystyki emisji zanieczyszczeń w postaci zależności emisji drogowej zanieczyszczeń od prędkości średniej samochodu. Badania są wykonywane dla skumulowanej kategorii samochodów osobowych, obejmującej samochody osobowe z silnikami o zapłonie iskrowym i o zapłonie samoczynnym, o różnych objętościach skokowych i różnych kategorii ekologicznych $[1,2,4,6,9]$. Strukturę samochodów ze względu na ich liczność i intensywność użytkowania (przebiegi) przyjęto na poziomie 2009 r. w Polsce. Zastosowano w tym celu modele struktury, opracowane dla państw Europy Zachodniej (wykorzystano model dla Niemiec) [1], oraz opracowany przez autora model opóźnienia stanu motoryzacji w Polsce w stosunku do Europy Zachodniej [2, 3]. Przyjęto do badań przypadek emisji zanieczyszczeń z silników nagrzanych do temperatury normalnej eksploatacji.

\section{Badania właściwości probabilistycznych procesów emisji zanieczyszczeń z silników samochodowych dla różnych procesów prędkości średniej pojazdów}

Na rysunkach $1-4$ przedstawiono charakterystyki emisji zanieczyszczeń jako zależności emisji drogowej zanieczyszczeń z silników samochodów osobowych od prędkości średniej. Zanieczyszczeniami, których emisje są analizowane są tlenek węgla $\mathrm{CO}$, węglowodory $\mathrm{HC}$, tlenki azotu $\mathrm{NO}_{\mathrm{x}} \mathrm{i}$ cząstki stałe PM. Charakterystyki te wyznaczono z zastosowaniem baz danych zawartych $w$ oprogramowaniu INFRAS AG [9].

Badania symulacyjne emisji zanieczyszczeń przeprowadzono z zastosowaniem metody Monte Carlo [6, 10]. Jako charakterystykę punktową procesu prędkości przyjęto wartość średnią. W badaniach wartość średnią traktuje się jako wielkość przypadkową, charakteryzującą proces 


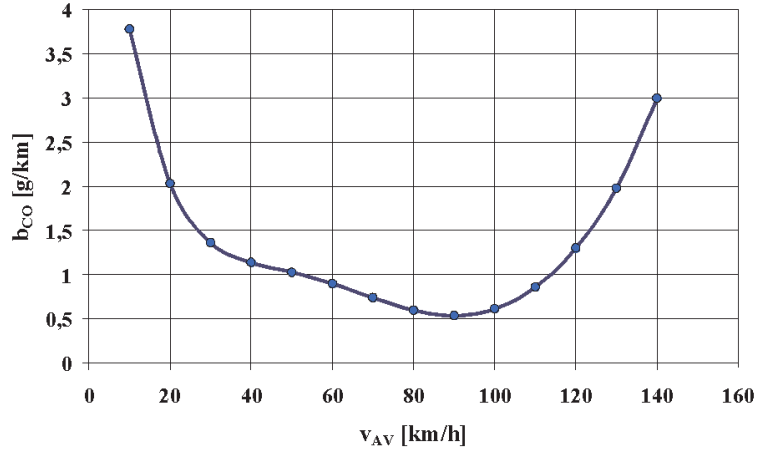

Fig. 1. The dependence of specific road emission of carbon monoxide $b_{C O}$ from passenger vehicle engines on the average speed $\mathrm{v}_{\mathrm{AV}}$

Rys. 1. Zależność emisji drogowej tlenku węgla $b_{C O}$ z silników samochodów osobowych od prędkości średniej $v_{A V}$

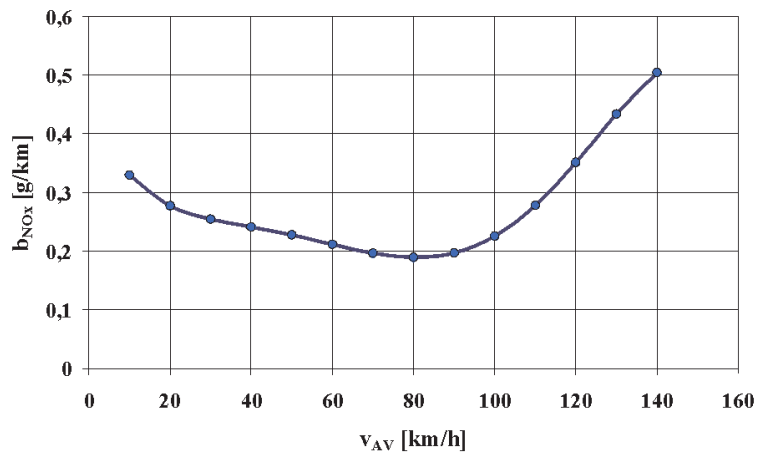

Fig. 3. The dependence of specific road emission of nitrogen oxides $b_{\mathrm{NOx}}$ from passenger vehicle engines on the average speed $\mathrm{v}_{\mathrm{AV}}$

Rys. 3. Zależność emisji drogowej tlenków azotu $b_{\text {NOx }}$ z silników samochodów osobowych od prędkości średniej $v_{A V}$

For the course of the average speed of even distribution a minimum value of $10 \mathrm{~km} / \mathrm{h}$ and a maximum value of 140 $\mathrm{km} / \mathrm{h}$ were assumed. For the course of average speed of the normal distribution the average value of $65 \mathrm{~km} / \mathrm{h}$ and the standard deviation of $35 \mathrm{~km} / \mathrm{h}$ were assumed. For the individual elements of the average speed sets the elements of the sets of road exhaust emissions were determined as per the characteristics presented in figures $1-4$. The analyses of the statistical properties of these sets of average speed and road exhaust emissions were carried out on standardized values [12].

Figure 5 presents the probability density $\mathrm{g}(\mathrm{x})$ of a standardized average speed (passenger vehicles) of constant distribution in the domain of value of course $\mathrm{x}$.

Figures 6-9 present the probability density of standardized exhaust emissions for the average speed of constant distribution.

Figure 10 collectively presents the probability density of a standardized average speed of passenger vehicles and a standardized road exhaust emissions for engines of passenger vehicles for the average speed of constant distribution. In order to ensure the clarity of the graph, the points of the discrete values of the density were joined with straight line.

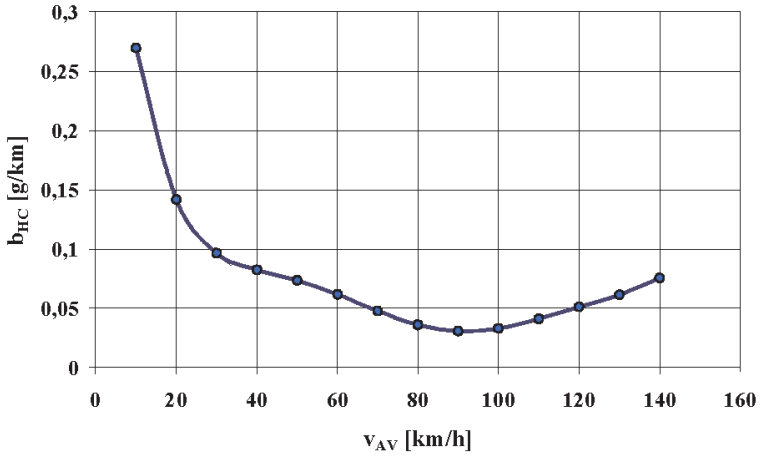

Fig. 2. The dependence of specific road emission of hydrocarbons $b_{\mathrm{HC}}$ from passenger vehicle engines on the average speed $\mathrm{v}_{\mathrm{AV}}$

Rys. 2. Zależność emisji drogowej węglowodorów $b_{H C}$ z silników samochodów osobowych od prędkości średniej $v_{A V}$

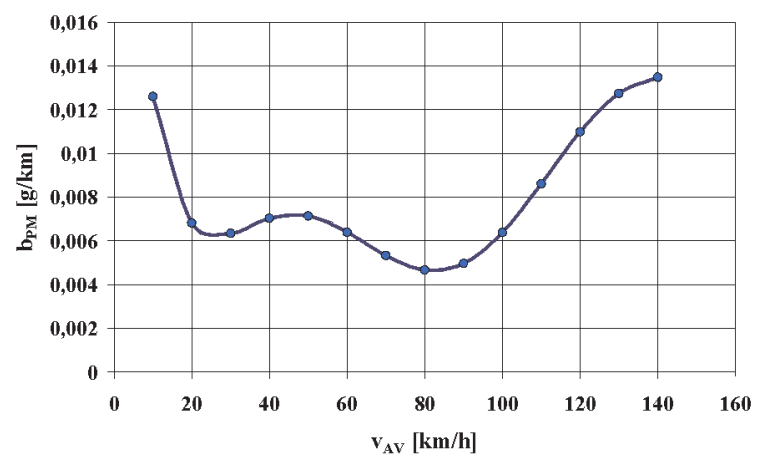

Fig. 4. The dependence of specific road emission of particulate matter $\mathrm{b}_{\mathrm{PM}}$ from passenger vehicle engines on the average speed $\mathrm{v}_{\mathrm{AV}}$

Rys. 4. Zależność emisji drogowej cząstek stałych $b_{P M}$ z silników samochodów osobowych od prędkości średniej $v_{A V}$

stochastyczny, zatem badania emisji zanieczyszczeń są wykonywane dla procesów stochastycznych o różnych charakterystykach, w szczególności o różnej wartości średniej. W niniejszym artykule rozpatruje się dwa procesy prędkości średniej samochodów osobowych o rozkładach: stałym (jednostajnym, równomiernym) i normalnym. Dyskretne wartości procesów prędkości średniej samochodu wyznaczono

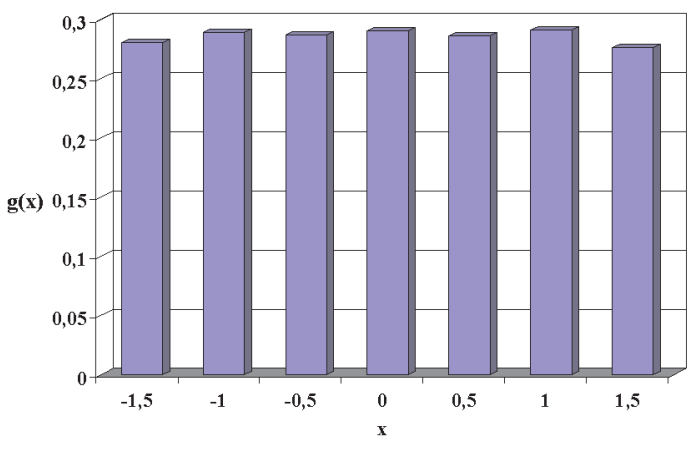

Fig. 5. The probability density $\mathrm{g}(\mathrm{x})$ of the standardized average passenger vehicle speed $\mathrm{v}_{\mathrm{AVs}}$ - constant distribution

Rys. 5. Gęstość prawdopodobieństwa $g(x)$ standaryzowanej prędkości średniej samochodów osobowych $v_{A V_{s}}$ - rozkład staty 


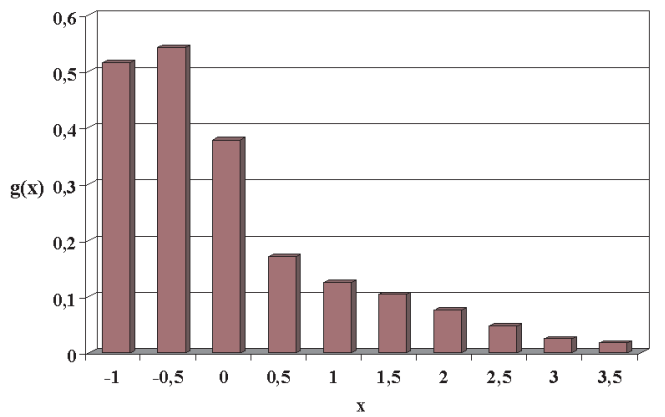

Fig. 6. The probability density $\mathrm{g}(\mathrm{x})$ of the standardized specific road emission of carbon monoxide $\mathrm{b}_{\operatorname{Cos}}$ from passenger vehicle engines

Rys. 6. Gęstość prawdopodobieństwa $g(x)$ standaryzowanej emisji drogowej tlenku węgla $b_{C O s}$ z silników samochodów osobowych

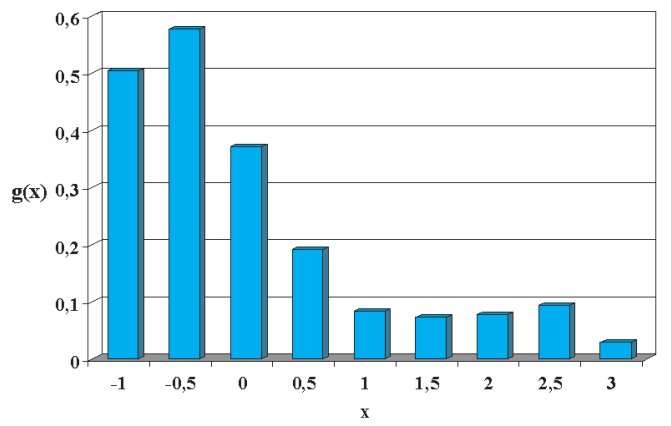

Fig. 8 . The probability density $\mathrm{g}(\mathrm{x})$ of the standardized specific road emission of nitrogen oxides $b_{\text {NOXs }}$ from passenger vehicle engines

Rys. 8. Gęstość prawdopodobieństwa $g(x)$ standaryzowanej emisji drogowej tlenków azotu $b_{N O x s} z$ silników samochodów osobowych

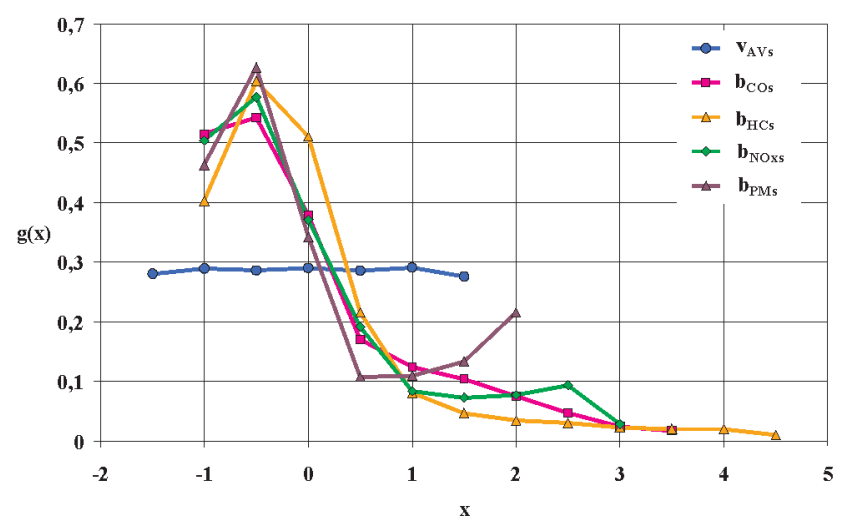

Fig. 10. The probability density of the standardized average passenger vehicle speed $\mathrm{v}_{\mathrm{AVs}}$ and of the standardized specific road emissions from passenger vehicle engines: $\mathrm{b}_{\mathrm{CO}}, \mathrm{b}_{\mathrm{HCs}}, \mathrm{b}_{\mathrm{NOXs}}$ and $\mathrm{b}_{\mathrm{PMS}}$

Rys. 10. Gestość prawdopodobieństwa $g(x)$ standaryzowanej prędkości średniej samochodów osobowych $v A V_{s}$ oraz standaryzowanej emisji drogowej zanieczyszczeń z silników samochodów osobowych: $b_{C O S^{\prime}} b_{H C S}, b_{N O x S} i b_{P M}$

The sets of the road exhaust emissions have very asymmetrical distributions with a clear shift of the modal value towards lower values.

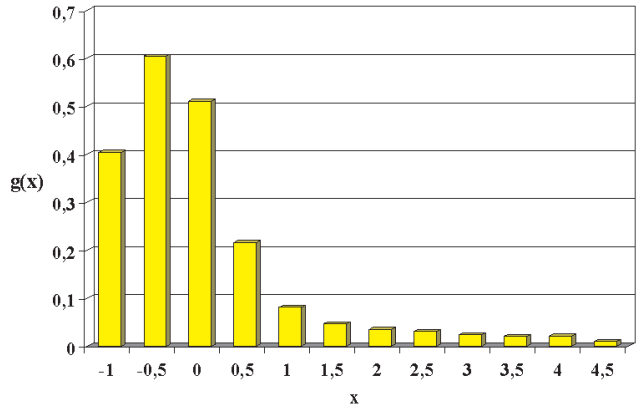

Fig. 7. The probability density $g(x)$ of the standardized specific road emission of hydrocarbons $\mathrm{b}_{\mathrm{HCs}}$ from passenger vehicle engines

Rys. 7. Gęstość prawdopodobieństwa $g(x)$ standaryzowanej emisji drogowej węglowodorów $b_{H C S} z$ silników samochodów osobowych

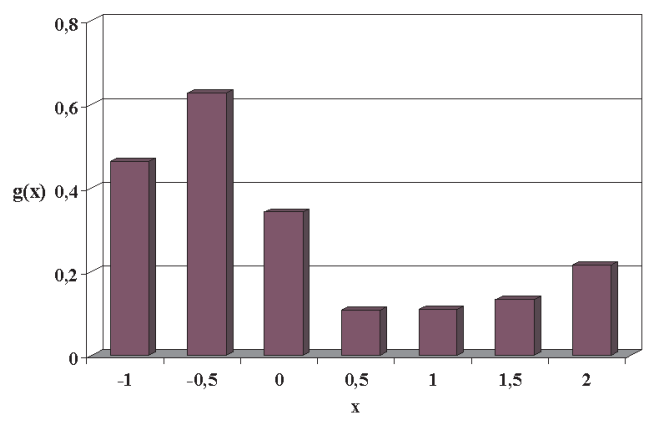

Fig. 9. The probability density $g(x)$ of the standardized specific road emission of particulate matter $\mathrm{b}_{\mathrm{PMS}}$ from passenger vehicle engines

Rys. 9. Gęstość prawdopodobieństwa $g(x)$ standaryzowanej emisji drogowej czastek statych $b_{P M s} z$ silników samochodów osobowych

dla każdego procesu w 15000 punktów z zastosowaniem generatora liczb pseudoprzypadkowych, stanowiącego wyposażenie oprogramowania Statistica.

Dla procesu prędkości średniej o rozkładzie stałym przyjęto wartość minimalną równą $10 \mathrm{~km} / \mathrm{h}$, a maksymalną $140 \mathrm{~km} / \mathrm{h}$. Dla procesu prędkości średniej o rozkładzie normalnym przyjęto wartość średnią $65 \mathrm{~km} / \mathrm{h}$ i odchylenie standardowe $35 \mathrm{~km} / \mathrm{h}$. Dla poszczególnych elementów zbiorów prędkości średniej wyznaczono elementy zbiorów emisji drogowych zanieczyszczeń zgodnie z charakterystykami przedstawionymi na rysunkach $1-4$. Analizy właściwości statystycznych zbiorów prędkości średniej i emisji drogowej zanieczyszczeń przeprowadzono na wartościach standaryzowanych [12].

Na rysunku 5 przedstawiono gęstość prawdopodobieństwa $\mathrm{g}(\mathrm{x})$ standaryzowanej prędkości średniej samochodów osobowych o rozkładzie stałym w dziedzinie wartości procesu $\mathrm{x}$.

Na rysunkach 6-9 przedstawiono gęstość prawdopodobieństwa standaryzowanych emisji drogowych zanieczyszczeń dla prędkości średniej o rozkładzie stałym.

Na rysunku 10 przedstawiono w sposób zbiorczy gęstość prawdopodobieństwa standaryzowanej prędkości średniej samochodów osobowych oraz standaryzowanej emisji drogowej zanieczyszczeń z silników samochodów osobowych 
Figure 11 presents the probability density of the standardized average speed of passenger vehicles of normal distribution.

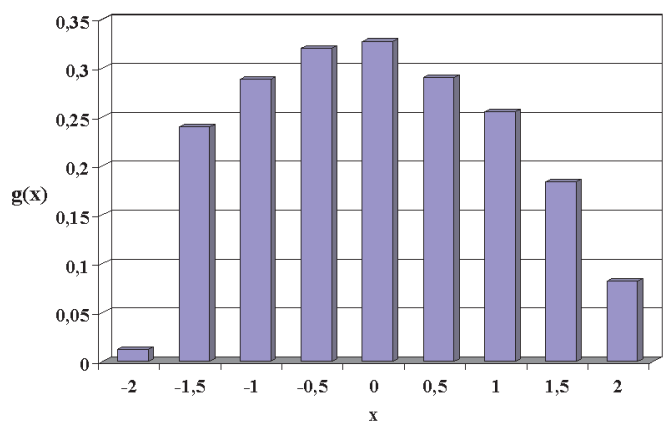

Fig. 11. The probability density $\mathrm{g}(\mathrm{x})$ of the standardized average passenger vehicle speed $\mathrm{v}_{\mathrm{AVs}}$ - normal distribution

Rys. 11. Gęstość prawdopodobieństwa $g(x)$ standaryzowanej prędkości średniej samochodów osobowych $v_{A V S}$-rozklad normalny

Figures $12-15$ present the probability density of standardized road exhaust emissions for the average speed of normal distribution.

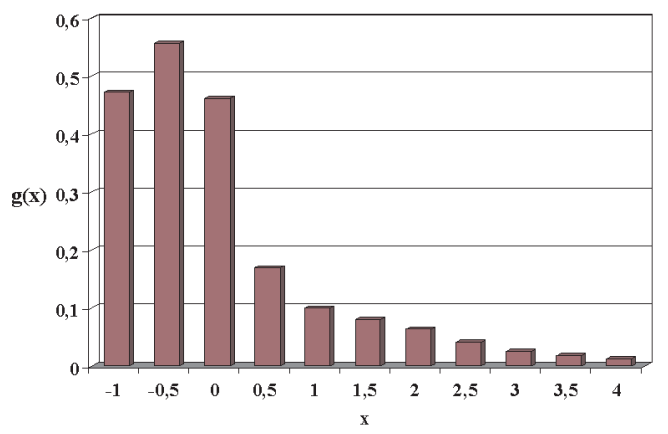

Fig. 12. The probability density of the standardized specific road emission of carbon monoxide $\mathrm{b}_{\mathrm{COs}}$ from passenger vehicle engines

Rys. 12. Gęstość prawdopodobieństwa $g(x)$ standaryzowanej emisji drogowej tlenku węgla $b_{\text {Cos }}$ z silników samochodów osobowych

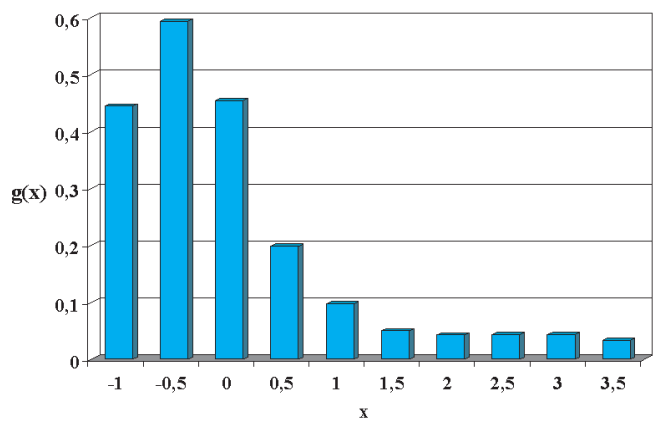

Fig. 14. The probability density of the standardized specific road emission of nitrogen oxides $b_{\text {NOxs }}$ from passenger vehicle engines

Rys. 14. Gęstość prawdopodobieństwa $g(x)$ standaryzowanej emisji drogowej tlenków azotu $b_{\text {Nors }}$ z silników samochodów osobowych dla prędkości średniej o rozkładzie stałym. W celu przejrzystości wykresu punkty dyskretnych wartości gęstości prawdopodobieństwa połączono odcinkami linii prostej.

Zbiory emisji drogowej zanieczyszczeń mają rozkłady bardzo niesymetryczne z wyraźnym przesunięciem wartości modalnej ku mniejszym wartościom.

$\mathrm{Na}$ rysunku 11 przedstawiono gęstość prawdopodobieństwa standaryzowanej prędkości średniej samochodów osobowych o rozkładzie normalnym.

Na rysunkach 12 - 15 przedstawiono gęstość prawdopodobieństwa standaryzowanych emisji drogowych zanieczyszczeń dla prędkości średniej o rozkładzie normalnym.

$\mathrm{Na}$ rysunku 16 przedstawiono gęstość prawdopodobieństwa standaryzowanej prędkości średniej samochodów osobowych oraz standaryzowanej emisji drogowej zanieczyszczeń z silników samochodów osobowych dla prędkości średniej o rozkładzie normalnym (z odcinkami linii prostej, łączącymi dyskretne wartości gęstości prawdopodobieństwa).

I w tym przypadku zbiory emisji drogowej zanieczyszczeń mają rozkłady znacznie niesymetryczne $\mathrm{z}$ tendencją przesunięcia wartości modalnej ku mniejszym wartościom (oprócz gęstości prawdopodobieństwa emisji drogowej cząstek stałych). W związku z tym zbadano charakterystyki

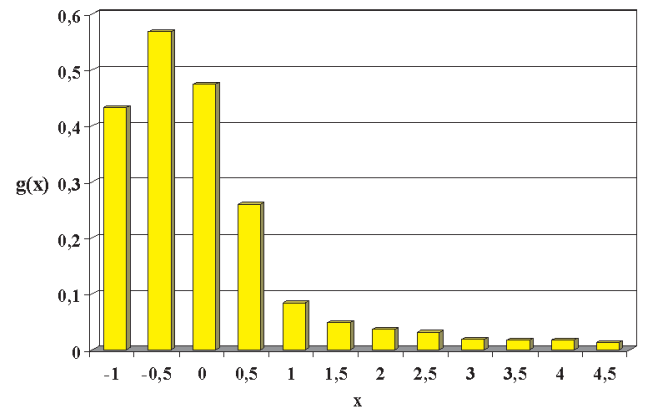

Fig. 13. The probability density of the standardized specific road emission of hydrocarbons $\mathrm{b}_{\mathrm{HCs}}$ from passenger vehicle engines

Rys. 13. Gęstość prawdopodobieństwa $g(x)$ standaryzowanej emisji drogowej węglowodorów $b_{H C s} z$ silników samochodów osobowych

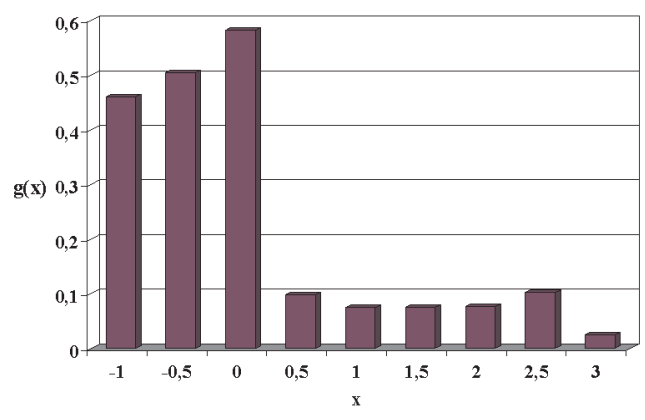

Fig. 15. The probability density of the standardized specific road emission of particulate matter $\mathrm{b}_{\mathrm{PMs}}$ from passenger vehicle engines

Rys. 15. Gęstość prawdopodobieństwa $g(x)$ standaryzowanej emisji drogowej cząstek statych $b_{P M s}$ z silników samochodów osobowych 
Figure 16 presents the probability density of the standardized average speed of passenger vehicles and standardized road exhaust emissions from passenger vehicles for the average speed of normal distribution (with the straight lines joining the discrete values of the probability density).

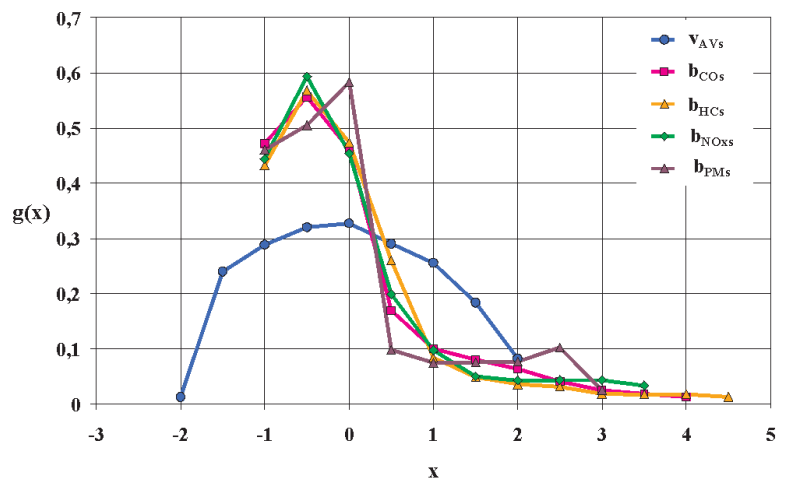

Fig. 16. The probability density of the standardized average passenger vehicle speed $\mathrm{v}_{\mathrm{AVs}}$ and of the standardized specific road exhaust emissions from passenger vehicle engines: $\mathrm{b}_{\mathrm{COs}}, \mathrm{b}_{\mathrm{HCs}}, \mathrm{b}_{\mathrm{NOxs}}$ and $\mathrm{b}_{\mathrm{PMs}}$

Rys. 16. Gęstość prawdopodobieństwa $g(x)$ standaryzowanej prędkości średniej samochodów osobowych $v A V$ S oraz standaryzowanej emisji drogowej zanieczyszczeń z silników samochodów osobowych: $b_{C O s}, b_{H C S}$, $b_{\text {NOxs }}$ i $b_{P M s}$

Also, in this case the sets of the road exhaust emissions have significantly uneven distributions with the tendency to shift the modal value towards lower values (except the probability density of the road emission of particulate matter). Hence, the investigations focused on the statistical characteristics of the sets of the average speed and standardized road exhaust emissions for both distributions of the average speed: constant- S and normal- N: median - Figure 17, kurtosis -Figure 18 and skewness coefficient- Figure 19.

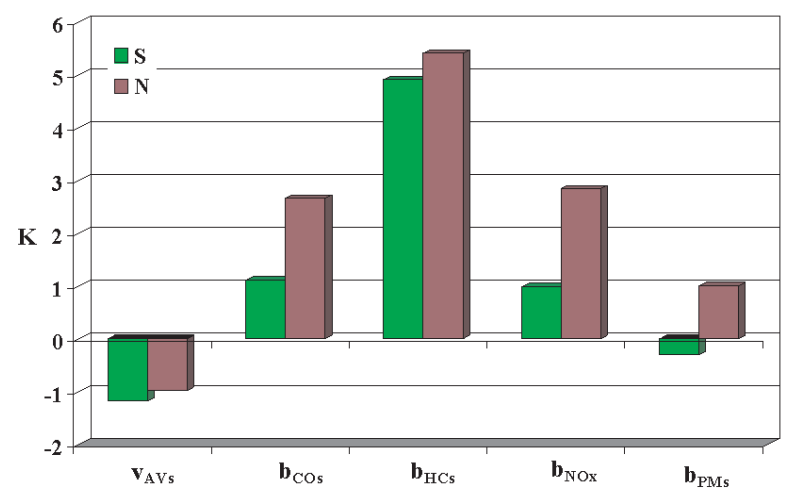

Fig. 18. The kurtosis $\mathrm{K}$ of the standardized average passenger vehicle speed $\mathrm{v}_{\mathrm{AVs}}$ and of the standardized specific road exhaust emissions from passenger vehicle engines: $b_{\mathrm{COs}}, b_{\mathrm{HCs}}, b_{\mathrm{NOxs}}$ and $\mathrm{b}_{\mathrm{PMs}}$

Rys. 18. Kurtoza K standaryzowanej prędkości średniej samochodów osobowych $v_{A V S}$ oraz standaryzowanej emisji drogowej zanieczyszczeń $z$ silników samochodów osobowych: $b_{C O S}, b_{H C S}, b_{N O x s} i b_{P M s}$

The analysis of the median, kurtosis and the skewness coefficient confirm the differences in the probability densities of the standardized emissions and standardized average statystyczne zbiorów standaryzowanej prędkości średniej i standaryzowanej emisji drogowej zanieczyszczeń dla obydwu rozkładów prędkości średniej: stałego - S i normalnego - N: medianę - rysunek 17, kurtozę - rysunek 18 i współczynnik skośności - rysunek 19.

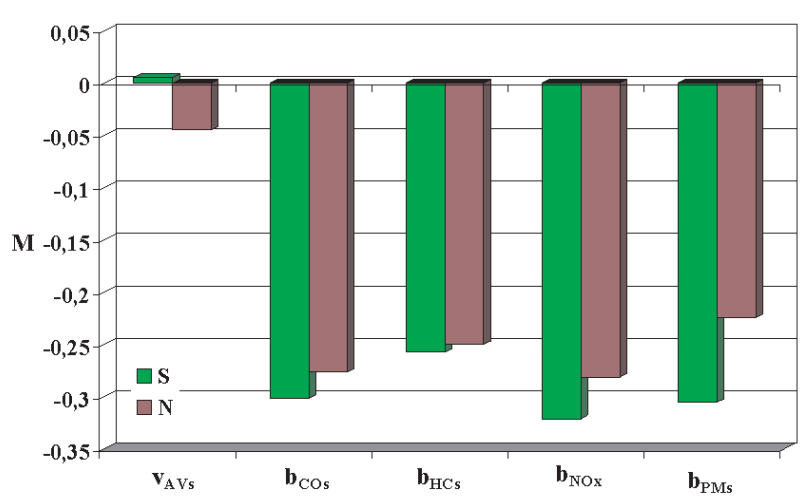

Fig. 17. The median $M$ of the standardized average passenger vehicle speed $\mathrm{v}_{\mathrm{AVs}}$ and of the standardized specific road exhaust emissions from passenger vehicle engines: $\mathrm{b}_{\mathrm{COs}}, \mathrm{b}_{\mathrm{HCs}}, \mathrm{b}_{\mathrm{NOxs}}$ and $\mathrm{b}_{\mathrm{PMs}}$

Rys. 17. Mediana M standaryzowanej prędkości średniej samochodów osobowych $v A V_{s}$ oraz standaryzowanej emisji drogowej zanieczyszczeń $z$ silników samochodów osobowych: $b_{C O s}, b_{H C S}, b_{N O x s}$ i $b_{P M s}$

Analiza mediany, kurtozy i współczynnika skośności potwierdza różnice $\mathrm{w}$ gęstościach prawdopodobieństwa standaryzowanej emisji drogowej zanieczyszczeń i standaryzowanej prędkości średniej - przesunięcie mediany ku mniejszym wartościom oraz mniejsze spłaszczenie rozkładów (rozkłady platykurtyczne [12]) i znaczną asymetrię rozkładów (rozkłady o prawostronnej asymetrii [12]).

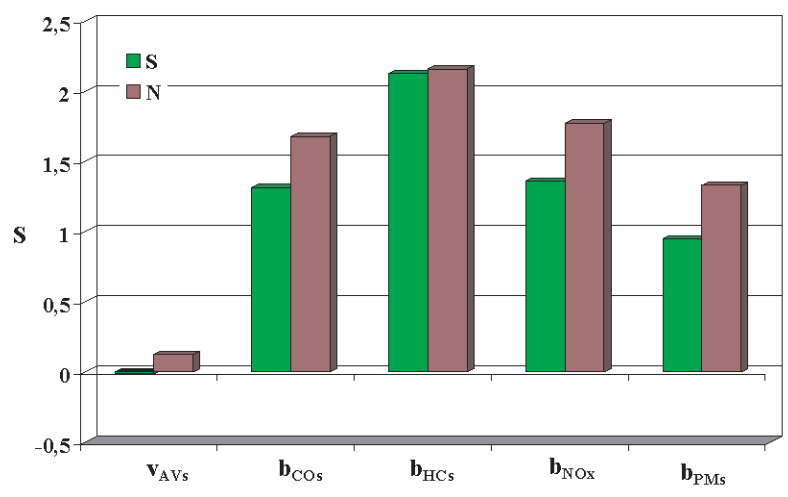

Fig. 19. The skewness coefficient $\mathrm{S}$ of the standardized average passenger vehicle speed $\mathrm{v}_{\mathrm{AVs}}$ and of the standardized specific road exhaust emissions from passenger vehicle engines: $\mathrm{b}_{\mathrm{CO}}, \mathrm{b}_{\mathrm{HCs}}, \mathrm{b}_{\mathrm{NOxs}}$ and $\mathrm{b}_{\mathrm{PMs}}$

Rys. 19. Współczynnik skośności S standaryzowanej prędkości średniej samochodów osobowych $v_{A V S}$ oraz standaryzowanej emisji drogowej zanieczyszczeń z silników samochodów osobowych: $b_{C O S}, b_{H C S}, b_{N O x s} i b_{P M s}$

\section{Podsumowanie}

Badania właściwości probabilistycznych emisji zanieczyszczeń z silników samochodowych nie należą do prac wykonywanych często, zarówno w Polsce [2 - 8], jak i w zagranicznych ośrodkach naukowych, mimo że dla użyt- 
speed- the shift of the median towards lower values and a smaller flattening of the distributions (platykurtic distributions [12]) and a significant asymmetry of the distributions (right-hand asymmetry distributions [12]).

\section{Conclusions}

The investigations on the probabilistic properties of the exhaust emissions from vehicle engines are rather seldom carried out worldwide including Poland [2-8] even though for the users of combustion engines, particularly tractive engines, the nature of the operating conditions is very characteristics which substantiates treating them as entirely random. For the examples under analysis there is a significant difference of the probability density of the courses of road emissions and the probability density of the course of the average speed, on which the course of the road emissions depends. The confirmed transformation of the probability density results from the non-linear characteristics of the exhaust emissions (Fig. $1-4$ ) that are relations between the road exhaust emissions and the average speeds, particularly the concaveness of the function that describes these characteristics. The consequences for the total exhaust emissions are, thus, important: in the case of typical distributions of average vehicle speeds, confirmed experimentally, for the total exhaust emissions the decisive are the moderate average speeds for which the road exhaust emissions are lower (sometimes much lower) rather than low or high average speeds. kowania silników spalinowych, szczególnie trakcyjnych, jest znamienna znaczna nieokreśloność warunków pracy, całkowicie uzasadniająca traktowanie ich jako przypadkowych. Dla rozpatrywanych przykładów występuje znaczna różnica gęstości prawdopodobieństwa procesów emisji drogowej zanieczyszczeń i gęstości prawdopodobieństwa procesu prędkości średniej, od której zależą procesy emisji drogowej zanieczyszczeń. Stwierdzona transformacja gęstości prawdopodobieństwa wynika z nieliniowości charakterystyk emisji zanieczyszczeń (rys. 1 - 4), będących zależnościami emisji drogowej zanieczyszczeń od prędkości średniej, w szczególności wklęsłości funkcji opisujących te charakterystyki. Konsekwencje dla emisji całkowitej zanieczyszczeń są - w związku z tym - istotne: w przypadku typowych rozkładów prędkości średniej samochodów, uzasadnionych doświadczeniem, dla emisji całkowitej zanieczyszczeń decydujące znaczenie mają umiarkowane prędkości średnie, dla których emisje drogowe zanieczyszczeń są mniejsze (niekiedy znacznie) niż małych i dużych prędkości średnich.

Paper reviewed/Artykut recenzowany

\section{Bibliography/Literatura}

[1] BUWAL, INFRAS AG: Luftschadstoffemissionen des Strassenverkehrs 1950-2010. BUWAL-Bericht Nr. 255. 1995.

[2] Chłopek Z.: Badania struktury ekologicznej pojazdów w państwach Unii Europejskiej ze względu na możliwość adaptacji modeli emisji do warunków polskich. Journal of KONES 2000.

[3] Chłopek Z.: Metody badań właściwości silników spalinowych w warunkach przypadkowych modelujących użytkowanie. Archiwum Motoryzacji 4/2001.

[4] Chłopek Z.: Modelowanie procesów emisji spalin w warunkach eksploatacji trakcyjnej silników spalinowych. Prace Naukowe. Seria „Mechanika” z. 173. Oficyna Wydawnicza Politechniki Warszawskiej, Warszawa 1999.

[5] Chłopek Z.: Testing of non-repeatability of pollution emission from motor-vehicle engines. Combustion Engines nr 1/2004 (118).

[6] Chłopek Z.: Zastosowanie metody Monte Carlo do wyznaczania ekologicznych charakterystyk silników. Journal of KONES 1998.

[7] Chłopek Z., Piaseczny L.: Statistical investigations of fast changeable processes in ship piston combustion engines. Polish Maritime Research No 2(44), 2005, Vol 12.
[8] Chłopek Z., Stasiak P.: The analysis of an unrepeatability of cylinder pressure signal in internal combustion engines. Combustion Engines nr 1/2005 (120).

[9] INFRAS AG: Handbuch für Emissionsfaktoren des Strassenverkehrs; Version 2.1; Bern 2004.

[10] Metropolis N., Ulam S.: The Monte Carlo Method. Journal of the American Statistical Association, Vol. 44, No. 247 (Sep., 1949), pp. 335-341.

[11] Sobczyk K.: Metody dynamiki statystycznej. PWN, Warszawa 1973.

[12] Wasserman L.: All of nonparametric statistics. Springer 2007.

Mr. Zdzisław Chłopek, DSc., DEng. - Professor in the Faculty Automotive and Construction Machinery Engineering at Warsaw University of Technology.

Dr hab. inż. Zdzisław Chłopek - profesor na Wydziale Samochodów i Maszyn Roboczych Politechniki Warszawskiej.

e-mail: moriarty@o2.pl 